\title{
The implementation of scientific learning at automotive engineering study program on vocational high school
}

\author{
Herminarto Sofyan, Zainal Arifin, Tafakur \\ Faculty of Engineering, Universitas Negeri Yogyakarta \\ Email: hermin@uny.ac.id
}

\begin{abstract}
The implementation of curriculum 2013 has changed some educational aspects. As the result, many problems appeared such as difficulties in conducting the authentic evaluation, implementing scientific learning using student-centered learning principle and encouraging the class to be active. To solve the problems, it is important to understand the implementation and problems of scientific learning at SMK. Therefore, a quantitative method with exposed facto approach was used to collect data. According to the results of the data analysis, it was concluded that: (1) the implementation of scientific learning: instructional planning, implementing, and evaluating was generally concluded by teachers. However, it was not conducted optimally for the weakness in "questioning" and "communicating" process. (2) some problems identified in the scientific learning implementation were: (a) difficulties in determining an instructional model and learning materials, (b) learning media limitation, (c) time management in the learning process, and (d) raising student motivation.
\end{abstract}

Keywords--curriculum 2013, scientific learning, learning problems

\section{INTRODUCTION}

Several challenges for the Indonesian nation in the globalization era encourage opened competition among some countries in various sectors of life. This is in line with the implementation of various pattern of trade and modern industry, such as ASEAN Economic Community (AEC) which become economic challenges. Although it's oriented for economic sector, it will affect to other sectors, such as employment and social sectors.

Not only external challenges, the internal challenges now also become an attention. For example, the number of productive age which reaches the peak in 2025-2035 has been the internal challenges for all countries and become a duty in order that the amount number become productive and burden less for the government (Permendikbud RI No. 70 the year of 2013 about the framework and curriculum structure in Vocational High School). According to the longtime demand, one of the government's efforts is by encouraging effective educational system.

The educational system in Indonesia has been developing through some changes of the curriculum. Now, curriculum 2013 has been implementing to change School-based
Curriculum. Appendix of regulation of Indonesia Minister Of Educational and culture RI Number 81A the year of 2013 about Implementation of Educational curriculum, states that: "Curriculum 2013 allows the principle that knowledge cannot be just transferred from a teacher to students. Students are subjects who have the ability to actively observing, analysing, constructing, and using knowledge." The changing of the curriculum required improvement of mindset and curriculum governance.

Curriculum 2013 initially be implemented simultaneously at all educational level in 2014/2015 school year. But, along with the implementation, some obstacles had risen, so the government give a police to stop for implementing the curriculum 2013 temporarily. Regulation of Indonesia Minister of educational and culture Number 160 year of 2014 about implementation of curriculum 2006 and curriculum 2013, article 1 states that: each basic and secondary education program which has implement curriculum 2013 since 1'st semester at 2014/2015 school year must return to implement curriculum 2006 starts from 2`nd semester at 2014/2015 school year until the provision from Indonesia Ministry of Education and Culture to reimplement curriculum 2013. Therefore, almost school had returned to implement curriculum 2006. According to the article 2 from the same policy, the school which has been appointed to become a pilot project for implementing curriculum 2013 can continue to implement curriculum 2013.

The changing of the curriculum does not only change the structure of the subject, but also educational paradigm at school. Many aspects were considered from philosophy, juridical, and conceptual aspects. With some change in the curriculum, changing curriculum is not easy as stated by the Minister of Education, Anies Baswedan (2014) states that: change the curriculum like changing the direction of an oil tanker. (http://news.detik.com /berita /2764027/ menteri anies-mengubah-kurikulum -ibarat-merubah-arah-kapaltanker). Hence, for implementing curriculum should consider readiness from all stakeholders.

Even the implementation of the new curriculum is challenging, most of the schools have not implemented the curriculum during this year. However, they have been pioneering path schools for curriculum implementation before being conducted comprehensively. Policy of ministry 
of education and culture Number 160 section 4 2014th year about the implementation of 2006 and 2013 curriculum, states that: "elementary and high schools are able to implement School-based Curriculum till the academic year of 2019/2020." Thus, all schools should prepare themselves in order to make the implementation goes expectedly

The implementation of Curriculum 2013 is the form of educational reformation to improve educational quality. The changing is a logical effect of the educational institution as a result of the politics, socio-culture, economic and technology changing in the society. Along with developments of multidimensional society at 21 'st century, all stakeholders in the educational institution have been founded with some requirements, such globalization literacy, financial and economic literacy, civic literacy, health literacy, environmental literacy, learning and innovation skills, information and technology skills, and life and career skills. (P21 Framework definition, 2009: 2-7).

Curriculum changing is always followed by various education and learning aspects. In line with the implementation of Curriculum 2013, several problems have been facing by schools. According to the opinions of the special staff of development controlling and managing of Minister of Education (UKMP3), Agnes Tuti Rumiyati in the dialog and national consultation related to Curriculum 2013, there are several problems in the implementation i.e. teachers have not understood yet about the assessment process and feel difficult to implement scientific approach and encourage the students active in the learning process ((http://news.okezone.com/read/2014/10/16/65/1052959/tiga -masalah-gurudalam-implemen-tasi-kurikulum-2013). These three problems are effects of the paradigm changing in Curriculum 2013.

The paradigm-changing in Curriculum 2013 influences the changing of the learning process at school. In the learning process, Curriculum 2013 has some changing and reinforcement form Curriculum 2006. According to the regulation of Indonesia Minister of education and culture Number 70 the year of 2013 about the basic framework and curriculum structure of vocational middle school, Curriculum 2013 is developed by improving the mindset from the previous curriculum including 1) the teachercentred to student-centred learning. The students should have choices towards learning materials to get the same competency; 2) one-way learning between the teacher and students to interactive learning (teacher-students-societyenvironment, and other learning resources); 3) isolated learning to network learning i.e. students are able to get knowledge from whoever and wherever contacted and from the internet); 4) passive learning to active learning (active learning is strengthened by scientific approach); 5) individual learning to team-based learning; 6) single-media learning to multimedia-based learning; 7) mass-based media to consumer needs by reinforcing students' particular potency; 8) mono-disciplinary learning to multidisciplinary learning; 9) passive learning to critical learning. Some reinforcement requires teachers to be able to design and manage to learn using a scientific approach. Another effect, the choice and implementation of the model, strategy, method and learning media should be designed to support the goals of learning by a scientific approach.

In the implementation of curriculum 2013, it uses learning approach, strategic, model, and method which enhance activity of students are: (1) interactive and inspiration, (2) pleasure, challenging, and motivating for student learning actively, (3) contextual and collaborative, (4) giving space for making student initiative, creative, and student independence, and (5) accordance with their talent, interests, ability, and physical and psychological development of the students. Regulation of Indonesia Minister of education and culture Number. 103 the year of 2014 states that: the instructional model is a conceptual framework and instructional operation have a name, feature, logical steps, arrangement, and culture. According to the policy too, an instructional method is style or technique used by the teacher for handling an instructional activity included speech, question and response, and discussion.

Sally Faraday (2011: 15) says that:" Each model can be described as a structured sequence, which is designed to elicit a particular type of thinking or response, to achieve specific learning outcomes". The learning models will direct the learning based on the learning approaches. For implementing the scientific approach in curriculum 2013, three main models of learning to form scientific and social attitude as well as to develop curiosity (Permendikbud No. 103 the year of 2014) can be used. Those three models are Problem-based Learning, Project-based Learning and Discovery/Inquiry Learning. Additionally, Production Based Education (PBE) in line with the characteristics of Vocational High School is also produced.

Learning with scientific approach can be assumed to research-based learning/ observations. Therefore, this study strongly advised the government to implement the curriculum 2013. Compared with the conventional learning, learning with research-based scientific / observation has the advantage that it can be seen in Table 1.

TABLE 1. COMPARISON OF LEARNING RESULTS OF TRADITIONAL LEARNING AND SCIENTIFIC APPROACH LEARNING (CARL WIEMAN, 2007)

Traditional learning $\quad$ Scientific based learning

Retention of information from Retention of information from lecture: lecture: $10 \%$ after 15 minutes $\quad$ More than $90 \%$ after 2 days

Gain in conceptual The gain in conceptual understanding: \begin{tabular}{l|l} 
understanding: $25 \%$ & $50-70 \%$ \\
\hline
\end{tabular}

Beliefs about physics and A small improvement

problem-solving: significant

drop

Whatever model, strategy, method or learning media used, the scientific approach should be applied. Teachers should plan learning procedure in line with learning models used that refer to the scientific approach. $\mathrm{TH}$ relationship with a scientific approach, the steps have been clearly determined. Appendix of regulation of Minister of education and culture Number $81 \mathrm{~A}$ the year of 2013 about the implementation of curriculum states that scientific approach in Curriculum 2013 has five steps: observing, questioning, collecting information, associating and communicating. To 
reach effective learning, teachers should make a learning plan in conformity with those five steps with appropriate model, strategy, method and learning media.

The educational paradigm changing that influences the learning process also affect the learning evaluation. The scientific learning evaluation should be able to assess various aspects authentically. Therefore, learning evaluation in Curriculum 2013 goes through some reinforcement to reach authentic assessment. This is supported by Regulation of Minister of education and culture Number 53 the year of 2015 about the assessment of learning outcome by educators and school unit in elementary school and middle school section5 that "The scope of the study results of the teachers includes attitude, knowledge and skill." Thus, the evaluation should be able to measure the students' competencies comprehensively. Further, according to the clarification by vice Minister of Educational and culture in the educational sector about concept and implementation curriculum 2013 date January 14th, 2014 points out that the assessment should support students' creativity and measure students' task completion instead of its result.

Based on the various challenges, facts, and rules about the implementation of Curriculum 2013, there are many challenges faced by schools as well as teachers in various aspects of education including in the learning. In the implementation of Curriculum 2013, there are several problems faced by teachers such as they have not understood yet the process of authentic assessment, scientific learning process, and how to manage the class. As a result, the implementation of scientific learning is needed to be seen from the learning planning, process and evaluation. Regarding to several problems stated, this research was aimed to (1) know the implementation of scientific learning by considering the scientific learning planning, process and evaluation in Auto Vehicle Engineering department at Vocational High School, and (2) know several problems facing teachers in the scientific learning implementation from the planning, process, and the evaluation.

\section{METHODS}

This research used quantitate method with the exposed facto method. This was aimed to reveal the facts about the scientific learning implementation with the problems faced by teachers of Auto Vehicle Engineering department at Vocational High School implemented Curriculum 2013 The year 2016 in Sleman. The collecting data techniques used were questionnaire and interview while the instrument used were questionnaires and an interview guide. Then, quantitative data were analysed using the descriptive quantitative technique to determine the scientific learning process from the planning, process and evaluating. Moreover, the data were visualized using diagram/graphics in interpreting the data. Additionally, the interview results were employed to enrich the quantitative analysed results

\section{RESULTS AND DISCUSSION}

Based on research about the implementation of scientific learning in the curriculum 2013, there were 4 vocational schools in Sleman district, consists of 2 regular vocational schools and 2 private vocational schools. The schools were a pilot school in curriculum 2013 so that after the publication of the Permendikbud RI No. 140 the year of 2014, it's still implemented curriculum 2013. Thus, this schools had been conducting a scientific approach to learning with the appropriate provisions contained in the Permendikbud RI No. 103 the year of 2014. Curriculum 2013 requires the paradigm changing that emphasizes on: (1) studentscantered, (2) developing students' creativity, (3) creating enjoyable and challenging condition, (4) having value, ethics, aesthetics, logic and kinaesthetic, (5) providing various learning experiences through conducting variously enjoyable, contextual, effective, efficient, and meaningful learning strategies and methods (Regulation of Minister Of Educational and Culture Number 81A year of 2013 about curriculum implementation). In the implementation, the scientific learning is used in the learning process in Curriculum 2013.

Data on the implementation of scientific learning were looked from the perspective of learning as a system. The instruction activity consists of input, process, until learning outcomes. Implementation of the scientific approach starts from the planning process of learning, the implementation of learning activities, and the evaluation of learning activities. Thus, the data obtained to determine the views of scientific learning implementation planning aspects of learning, scientific learning activities, and the evaluation process on learning with the scientific approach

\section{The implementation of scientific learning}

According to the descriptive quantitative analysis results from the planning, process and evaluation of scientific learning, the implementation was found out much than the ideal standard as presented in Table 2.

TABLE 2. IMPLEMENTATION OF INSTRUCTIONAL ASPECTS

\begin{tabular}{|c|l|c|c|}
\hline No & \multicolumn{1}{|c|}{ Aspects } & Mean & Ideal score \\
\hline 1 & Planning & 3,49 & 4,00 \\
\hline 2 & Learning activity & 2,89 & 4,00 \\
\hline 3 & Evaluation & 3,41 & 4,00 \\
\hline
\end{tabular}

To interpret the data about instructional aspect implementation easily, the data will be compared with ideal score presented in Figure 1.

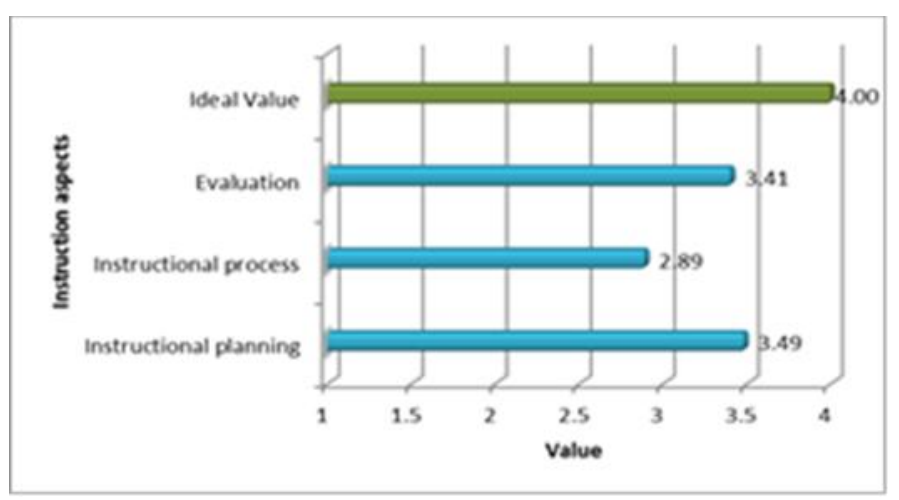

Fig 1. Scientific learning implementation 
Based on the frequency of the teachers who conduct planning based on aspects of scientific learning planning, some teachers had some problems are: the ability of students was not support scientific learning ( $25 \%$ of teachers), as well as $18 \%$ of teachers, do not plan attitude evaluation. Based on the diagram above, the learning process got the lowest score than the ideal standard. Thus, the implementation of scientific learning has not been conducted well than the learning planning and evaluation. However, all aspects above could be conducted well perceived from the ideal implementation.

The scientific learning implementation was the lowest aspect based on the implementation. The diagram below showed from the steps of the scientific learning: observing, questioning, collecting data, associating, and communicating, the implementation would be:

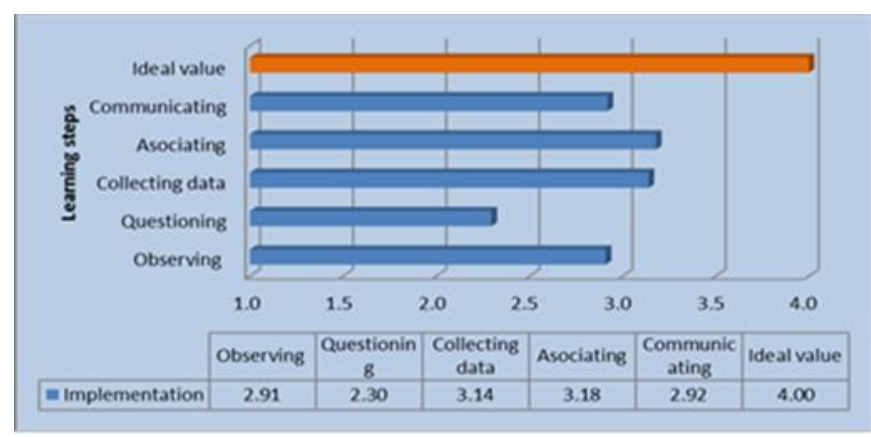

Fig 2. Implementation of Scientific Learning Steps

Based on the accomplished learning procedure above, "questioning" attained the lowest score among other steps i.e. 2.30 of the ideal score 4.0. Thus, it could be concluded that in the implementation of scientific learning, there were many teachers that have not been able to encourage students to propose questions. Another step that has not been conducted well was "observation" and "communicating" i.e. 2.91 and 2.92. This was in line with the interview results with the teachers:

a. Many teachers have not conducted observation on various sources because they found difficulties in determining the observation object.

b. The students' had low motivation to propose questions and not used to the learning.

c. The students were not used to communicate the discussion results, tend to be passive so that they needed more stimulus.

The following table presented the evaluation form (process and results) and the evaluation aspects: attitude, knowledge and skill evaluation.

TABLE 3. IMPLEMENTATION OF SCIENTIFIC LEARNING EVALUATION

\begin{tabular}{|l|l|l|l|}
\hline \multicolumn{2}{|l|}{ Evaluation form } & Mean & Ideal score \\
\hline Form of evaluation & Process & 3.61 & 4,00 \\
\cline { 2 - 4 } & Product & 3.27 & 4,00 \\
\hline Evaluation aspects & Afective & 3.59 & 4,00 \\
\cline { 2 - 4 } & Knowledge & 3.80 & 4,00 \\
\cline { 2 - 4 } & Skill & 3.55 & 4,00 \\
\hline
\end{tabular}

According to the evaluation form on the data in Table 3, the evaluation score of the product was low (3.27). It means that the evaluation of the students' product has not run well. Meanwhile, from the evaluation aspects, the skill evaluation was the lowest than attitude and knowledge. It means that teachers have not conducted the skill evaluation well. It was also supported by the results of the interview dealing with the evaluation in which all competencies were not evaluated instead of particular competencies that were possible to be conducted caused by the limitation of evaluation media and facility.

\section{The problems of scientific learning}

The problems in the implementation of scientific learning included the problems in the learning planning, process and evaluation. Based on the data obtained, the problem level is presented in Picture 3.

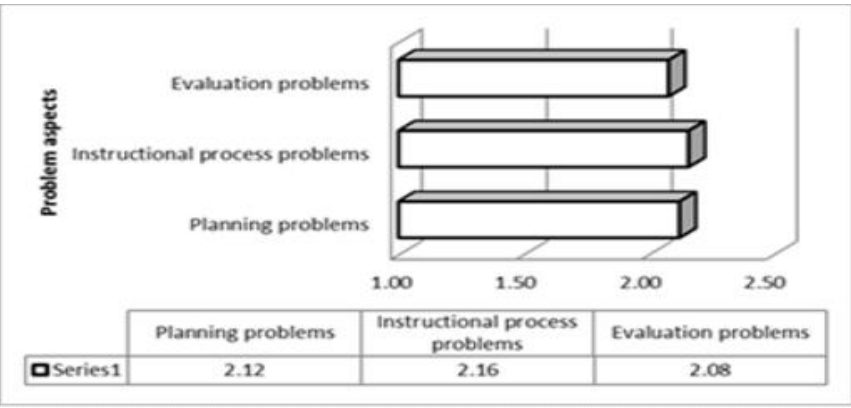

Fig 3. Problems of scientific learning

Based on the data obtained, the highest problem was the learning process i.e. 2.84. It was in line with the scientific learning condition that the process of scientific learning was the lowest than the learning planning and evaluation. It was also supported by the results of the interview dealing with the problems in the scientific learning as presented in Table 4.

TABLE 4. THE PROBLEMS OF SCIENTIFIC LEARNING BASED ON INTERVIEW RESULTS

\begin{tabular}{ll}
\hline $\begin{array}{l}\text { Instructional } \\
\text { aspects }\end{array}$ & Problems \\
\hline $\begin{array}{l}\text { Planning } \\
\text { instruction }\end{array}$ & $\begin{array}{l}\text { Difficulties in determining instructional model } \\
\text { Difficulties of determining teaching materials } \\
\text { Difficulties in determining teaching media } \\
\text { Difficulties fulfil administrations } \\
\text { Less understanding curriculum 2013 }\end{array}$ \\
\hline Implementing & $\begin{array}{l}\text { The students were not ready to learn } \\
\text { learning activity }\end{array}$ \\
& $\begin{array}{l}\text { Limitation of learning facilities } \\
\text { Incorrect instructional model } \\
\text { Time management } \\
\text { Limitation of observation sources }\end{array}$ \\
\hline Evaluating & $\begin{array}{l}\text { Evaluation item was too complex } \\
\text { Limitation of time allocation } \\
\text { Unsupported student abilities } \\
\text { Uncompleted media }\end{array}$ \\
\hline
\end{tabular}

Based on the interview results in Table 2, many problems were faced by teachers in implementing scientific learning.

Scientific learning was indirect teaching focused on student-centred learning. Scientific learning was emphasized by Curriculum 2013. The changing makes the paradigm 
changes as well. As a result, the implementation of scientific learning should be followed by the implementation of learning models in line with the paradigm of Curriculum 2013. Scientific learning could be ideally conducted with various learning models. According to Permendikbud No. 103 Tahun 2014, the learning process in Curriculum 2013 can be conducted through several learning models to develop creativity to create a scientific attitude, social attitude, and curiosity. They are Problem-based Learning, Project-based Learning and Discovery/Inquiry Learning. Production Based Education (PBE) can be also conducted in line with the characteristics of Vocational High School. However, because of the basic changing, many problems come up in its implementation.

Scientific learning in the curriculum 2013 implementation was implemented with the principle of student-centred learning. The instruction process was based on science activity. Scientific Learning was an active learning which very beneficial for learning science and engineering at all levels (Carl Wieman and Sarah Gilbert, 2011, p.203). Thus, scientific learning can support learning in Light Vehicle Engineering program.

Scientific approach learning can be implemented with direct or indirect learning mode dependent on the basic competence which should be achieved. With the demands of change, the learning paradigm is also changed. Consequently, in implementing the scientific study should be followed by the implementation of the model, the strategy and the learning method in accordance with the paradigm of the curriculum 2013 and the characteristics of the basic competencies to be achieved.

Ideally, scientific learning can be implemented with a variety of learning models. In accordance with Permendikbud No. 103 Tahun 2014, learning in the curriculum 2013 can be carried out with several models of learning to develop creativity, form a scientific behaviour, social behaviour and develop a sense of curiosity. All three models are Problem Based Learning model (Problem-Based Learning), Project Based Learning model (Project-Based Learning), and the model of Learning Through discovery (Discovery/ Inquiry Learning). In addition, the learning model Production Based Education (PBE) may also be applied according to the characteristics of vocational education. However, due to some fundamental change, many problems were encountered among the teachers in implementing this learning.

\section{Planning the Scientific Learning}

Planning the learning is an activity that determines the success of learning. There are some tasks in this plan, such as: formulating indicators of achievement of competencies, analysing the characteristics of the students, determining teaching materials, determining the instructional model, instructional media, instructional strategies and actions, planning the evaluation of learning. Based on the analysis, it is known that scientific learning plan can be implemented through the RPP made by the teacher. It can be seen from the mean score achievements are 3.49 from the ideal value of
4.00. Nevertheless, there are still $2 \%$ of teachers do not carry out the study with good planning.

Based on the frequency in conducting the planning of scientific learning, several teachers gave negative opinions: the students' ability did not support scientific learning $(25 \%)$, and $19 \%$ of teachers did not conduct the attitude evaluation. It happened because teachers found difficulties to map out the learning: analysing students characteristics $(46 \%)$, determining learning strategy (32\%), and preparing learning media and resource $(28 \%)$. It was caused by various difficulties or problems in implementing scientific learning. Thereupon, to analyse students' characteristics: intelligence, social, economic, and other aspects were difficult for teachers to determine the appropriate learning models. This would influence the decision of learning strategy, method, media and resource that can support learning activities. Killen (2009: 84) states that: there are many ways to consider the selection of learning strategies, but the most important thing to remember is to choose a strategy based on the capabilities of what is expected of students as a result of learning. Killen (2009: 85) also states that: there are no better learning strategies than other strategies for all circumstances, so a teacher should be able to use a variety of learning strategies and determine rational decisions regarding learning strategy chosen. Thus, in determining the strategy of learning, teachers must consider a variety of things when planning lessons.

According to the analysing results of the problems in the planning, there are several problems: (1) determining the learning model, (2) determining the learning materials, (3) determining the learning media, (4) fulfilling the administration and (5) unfamiliarity of Curriculum 2013. Further, the teachers' ability in planning the learning should be improved. In determining the learning model, teachers need to acknowledge student and learning materials characteristics. Thus, they can choose learning models: Problem-based Learning, Project-based Learning, Discovery/Inquiry-based Learning or other learning models which use a scientific approach.

\section{Scientific learning process}

The aspects of scientific learning process have not run well. The achievement score is 2.89 , lower than the learning planning score (3.49) and learning evaluation (3.41). Teachers have actually conducted the learning planning but it was not good enough. This is in accordance with the recognition of the teacher that the teacher can plan to learn, but the implementation is often not in line with expectations. As a result, teachers have to change the strategy of learning, and sometimes back to the conventional way to achieve learning targets. Learning process in the curriculum 2013 required to change a paradigm in teaching that emphasizes the following principles: (1) centered on the learner, (2) develop the creativity of learners, (3) creating conditions fun and challenging, (4) uncharged values, ethics, aesthetics, logic, kinesthetic, and (5) provide a diverse learning experience through the application of various strategies and methods of learning fun, contextual, effective, efficient, and meaningful (Permendikbud No. 81A Year of 2013 about curriculum implementation). Thus, the instruction must carry 
out based on the improvement mindset to support the development of student creativity, compared with many teachers on curriculum implemented in 2006.

Regarding the scientific learning process: observing, questioning, collecting data, associating and communicating, there are several steps that have not run well: questioning (2.30), observing (2.91), and communicating (2.92) of the ideal score, 4.00. The procedure of scientific learning should be carried out well as using whatever learning models. The procedure should be carried out in accordance with the selected learning model. Regards to Permendikbud No. 81A Year of 2013, explained that the move "ask" emphasis on learning by asking questions about information that is not understood from what is observed or questions to gain additional information about what is observed (starting from factual questions to the hypothetical question). This activity was aimed to develop creativity, curiosity, the ability to formulate questions, to form the critical mind, the need for intelligent living and lifelong learning. Therefore, teachers should be more emphasis on students to do activities at this stage to provide better opportunities to the students to want to ask.

Steps of scientific learning must be conducted properly when using any learning model. From observing step to communications, must be accomplished in accordance learning model selected. But, there were several problems that make the learning process does not run well:

a. The learning at the ready of students. It happened because they are not familiar with the learning model applied. Teachers should choose the appropriate learning model, materials and the students' characteristics

b. The limitation of facilities. The limitation of learning facilities will influence teachers' freedom to carry out the learning in accordance with the learning model used. Every step of scientific learning could be carried out by teachers creatively if the learning facilities support as well. Teachers should be creative to use the facilities as the observation object in accordance with the learning materials

c. The inappropriate learning models. In the implementation of scientific learning, many teachers found difficulties in determining the appropriate learning model. Consequently, the learning strategy planned cannot run well. Uno (2012:2) points out that learning strategy is defined as the ways that will be chosen and used by a teacher to deliver the learning materials in order to make students understand the learning materials easily in order to achieve the goal of learning eventually. Thus, the inappropriate ways to manage the learning will make the functions and roles of strategy and learning model are not optimal. It is in line with Killen's opinion (2009:84) that there are many ways in considering the learning strategy, however the most important to remember is determining the strategy based on the competency expected from students as the study results. The inappropriateness strategy or learning model will hinder the implementation of scientific learning procedure.

d. Poor time management. Learning should be designed in accordance with the time allocation. However, many teachers still found difficulties to implement scientific learning in line with the time allocation. In fact, implementing scientific learning makes some teachers use more time to reach learning target, so almost teacher change the learning approach back to traditional learning. The teachers belonging plan the learning properly with appropriate method, model, and learning strategies based on characteristics of learned competencies. Teachers can use direct teaching mode or indirect mode for making effective learning (Regulation of Indonesia Ministry of education and culture Number 103 The year of 2013).

e. The limitation of learning materials and observation resource. In the observation process, students can use various physic learning source and other sources. Observation resources can be creatively and interestingly designed to motivate and stimulate students' questions.

Good learning activities would be appropriate for the planning. In addition, in the learning process, teachers should have principles on student-centred learning paradigm. Unmotivated students should be overcome by teachers as the beginning of learning. Teachers should pay attention and raise students' motivation externally such as giving nice welcome, giving examples and elaborating the necessity of materials and its relationship with the future profession. Moreover, in determining the learning models, several factors such as students' characteristics, materials, resources, and goal of learning should be taken into account. Therefore, with the application of active learning, then the results will take students to learn more compared with conventional learning (Carl Wieman dan Sarah Gilbert, 2015, p. 152).

\section{Scientific learning evaluation}

The evaluation in scientific learning can be categorized according to the form and assessment aspects. In terms of the evaluation form, there are process and results evaluation. Meanwhile, in terms of assessed aspects, there are attitude, knowledge and skill evaluation. The scientific learning evaluation conducted by teachers is presented in figure 4 .

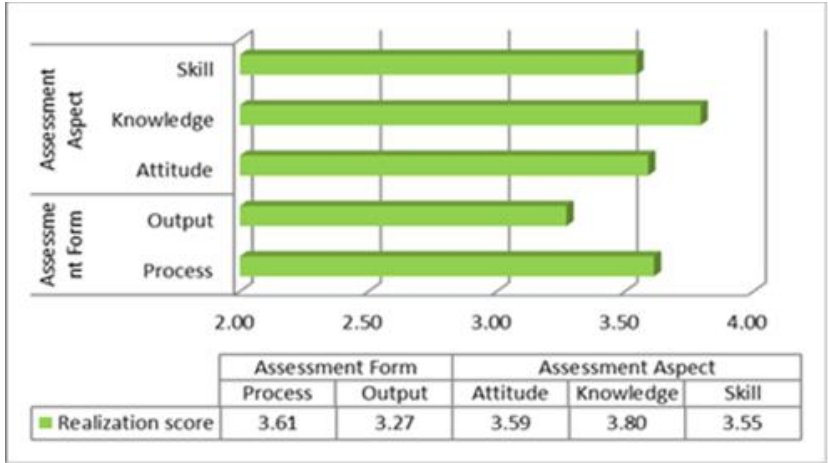

Fig. 4. Implementation of scientific learning evaluation

Based on Picture 4, the mean of the achievement score of the analysis results is 3.41. However, product and skill assessment do not look optimal yet. It is caused by several problems as follows.

a. The complexity of evaluation elements. The scientific learning evaluation needs to meet the learning model applied. Evaluation needs all competencies 
comprehensively: affective, cognitive and psychomotor. Yet, many teachers find the evaluation elements complex. Thus, they should manage the planned evaluation to be able to run well.

b. Time limitation. Many teachers complain about time limitation. They should manage time to evaluate in order to be in accordance with the evaluation type used. Many alternatives can be applied by teachers to conduct process or result evaluation in accordance with the authentic assessment.

c. The unsupported ability of students. According to teachers, students' ability is low in the scientific learning. It is caused by the unfamiliarity of teachers and students on scientific learning. Nevertheless, with teachers' creativity, students' potency can be developed in accordance with the goal of scientific learning which is improving students' creativity. Consequently, learning model and strategy used should be appropriate for students' needs and materials requirements.

d. The insufficient evaluation media. Another problem in carrying out scientific learning evaluation is the media limitation. The most media limitation is the practical media. They hinder teachers to create a various evaluation for the practical learning.

\section{CONCLUSION}

Based on the data analysis results stated before, it can be concluded as follows.

Firstly, the implementation of scientific learning in Auto Vehicle Engineering department in Sleman according to the learning planning, process and evaluation have been generally carried out. However, the learning process has not run well and effectively. It is caused by the weaknesses in "questioning" and "communicating" in the scientific learning.

Secondly, there are several types of scientific learning implementation in Vocational High School including the learning planning, process and evaluation. It was caused by several problems: (a) difficulties in determining the learning model, (b) difficulties in determining the appropriate learning materials and observation source, (c) the limitation of learning media and facilities, (d) difficulties in managing the learning in accordance with time allocation, and (e) difficulties to stimulate students' motivation and creativity.

\section{REFERENCES}

[1] Anonim. 2014. Menteri Anies: Mengubah Kurikulum Ibarat Merubah Arah Kapal Tanker. http://news.detik.com/berita /276 4027/menterianies-mengubah kurikulum -ibarat-merubah-arah-kapal-tanker. diakses pada tanggal 20 Februari 2016.

[2] Carl Wieman dan Sarah Gilbert. 2015. Taking a Scientific Approach to Science Education, Part I - Research. Microbe, 10.4, 152-156.

[3] Carl Wieman dan Sarah Gilbert. 2015. Taking a Scientific Approach to Science Education, Part II-Changing Teaching. Microbe, 10.10, 203-307.

[4] Carl Wieman. 2007. Why not try a scientific approach to science education.

https://www.google.co.id/url?sa=t\&rct=j\&q=\&esrc=s\&source=web\& $\mathrm{cd}=2 \& \mathrm{cad}=$ rja\&uact $=8 \& \mathrm{ved}=0 \mathrm{ahUKEwj} 6 \mathrm{rdGmxcrQAhXBKY} 8 \mathrm{KHc}$ HeDDYQFgguMAE\&url=http\%3A\%2F\%2Fwww.cwsei.ubc.ca\%2Fr esources\%2Ffiles\%2FWieman-Change_Sept-Oct_2007.pdf\&usg= AFQjCNFnqNCjF-18s4mxHZLB6xn Azf6O9w\&bvm=bv.139782543,d.c2I. Diakses tanggal 20 Oktober 2016.

[5] Depdikbud. 2014. Peraturan Menteri Pendidikan dan Kebudayaan Nomor 160 Tahun 2014 tentang Pemberlakuan Kurikulum Tahun 2006 dan Kurikulum 2013.

[6] Depdikbud. 2014. Peraturan Menteri Pendidikan dan Kebudayaan Nomor 103 Tahun 2014 tentang Pembelajaran pada Pendidikan Dasar dan Pendidikan Menengah.

[7] Depdikbud. 2013. Peraturan Menteri Pendidikan dan Kebudayaan Nomor 70 tahun 2013 tentang Kerangka dasar dan struktur kurikulum Sekolah Menengah Kejuruan/madrasah Aliyah Kejuruan.

[8] Depdikbud. 2014. Paparan materi oleh Wakil Menteri Pendidikan dan Kebudayaan bidang Pendidikan, tentang konsep dan implementasi kurikulum 2013 tertanggal 14 Januari 2014.

[9] Depdikbud. 2013. Lampiran Peraturan Menteri Pendidikan dan Kebudayaan RI Nomor 81A tahun 2013 tentang Implementasi Kurikulum.

[10] Hamzah B. Uno. 2012. Model pembelajaran: menciptakan proses belajar mengajar yang kreatif dan efektif. Jakarta: Bumi Aksara.

[11] Killen, R. 2009. Effective teaching strategies: lesson from research and practice. South Melbourne: Thomson/Social Press.

[12] Margaret Puspitarini. 2014. Tiga Masalah Guru dalam Implementasi Kurikulum 2013. http://news.okezone.com/read /2014/10/16/65/1052959/tiga-masalah-guru-dalam-implementasikurikulum-2013. Diakses tanggal 5 Maret 2016 